\section{Behandling av akutt myelogen leukemi hos eldre}

KLINISK OVERSIKT

\section{HÅKON REIKVAM}

Medisinsk avdeling

Haukeland universitetssjukehus

og

Klinisk institutt 2

Universitetet i Bergen

Han har bidratt med initiering av arbeidet og manuskriptskriving.

Håkon Reikvam er ph.d., spesialist i indremedisin og i blodsjukdommar og førsteamanuensis. Han har vore med på å skrive og revidere dei nasjonale retningslinjene for diagnostikk og behandling av akutt myelogen leukemi.

Forfattaren har fylt ut ICMJE-skjemaet og oppgir ingen interessekonfliktar.

\section{JAKOB DALGAARD}

Medisinsk avdeling

Drammen sjukehus

Han har bidratt med faglege innspel, kommentarar og illustrasjon.

Jakob Dalgaard er dr.med., spesialist i indremedisin og i blodsjukdommar og er seksjonsoverlege. Han har vore med på å skrive og revidere dei nasjonale retningslinjene for diagnostikk og behandling av akutt myelogen leukemi.

Forfattaren har fylt ut ICMJE-skjemaet og oppgir ingen interessekonfliktar.

\section{SILJE JOHANSEN}

Medisinsk avdeling

Haukeland universitetssjukehus

Ho har bidratt med faglege innspel, kommentarar og illustrasjon.

Silje Johansen er lege i spesialisering i indremedisin og i blodsjukdommar. Forfattaren har fylt ut ICMJE-skjemaet og oppgir ingen interessekonfliktar.

\section{TOR HENRIK ANDERSON TVEDT}

Medisinsk avdeling

Haukeland universitetssjukehus

og

Klinisk institutt 2

Universitetet i Bergen

Han har bidratt med faglege innspel, kommentarar og illustrasjon.

Tor Henrik Anderson Tvedt er spesialist i indremedisin og i blodsjukdommar. Han har vore med på å skrive og revidere dei nasjonale retningslinjene for diagnostikk og behandling av akutt myelogen leukemi.

Forfattaren har fylt ut ICMJE-skjemaet og oppgir ingen interessekonfliktar. 
Medisinsk avdeling

Haukeland universitetssjukehus

og

Klinisk institutt 2

Universitetet i Bergen

Han har bidratt med manusskriving og koordinering av arbeidet.

$\emptyset y$ stein Bruserud er dr.med., spesialist i indremedisin og i blodsjukdommar og professor. Han har

vore med på å skrive og revidere dei nasjonale retningslinjene for diagnostikk og behandling av akutt myelogen leukemi.

Forfattaren har fylt ut ICMJE-skjemaet og oppgir ingen interessekonfliktar.

Akutt myelogen leukemi er ei gruppe aggressive, maligne blodsjukdommar som rammar alle aldersgrupper, men er vanlegast hos eldre over 65 år. Nyare behandlingsmetodar og nyare forsking indikerer at eldre pasientar også kan profittere på meir aktiv behandling.

Akutt myelogen leukemi er ei gruppe maligne blodsjukdommar med om lag 150 nye tilfelle årleg i Noreg. Median alder ved diagnosetidspunktet er 70 år, men sjukdommen kan ramme alle aldersgrupper (1). Årsaka til akutt myelogen leukemi er oftast ukjend (1), men kan oppstå etter tidlegare stråleterapi og kjemoterapi for annan malign sjukdom eller etter initial diagnose med meir låggradig malign hematologisk sjukdom (1).

Yngre pasientar vil i all hovudsak bli behandla med kurativ intensjon med intensivt kjemoterapiregime, eventuelt supplert med avsluttande stamcelletransplantasjon. Medan ein tidlegare reserverte denne behandlinga til pasientar under 6o-65 år, er ein no blitt merksam på at også ein del eldre pasientar kan tole og dermed ha nytte av slik behandling.

Sjukdomsstabiliserande behandling har dei siste tiåra kome som eit nytt behandlingskonsept ved akutt myelogen leukemi. Denne kurerer ikkje sjukdommen, men kan forlenge levetida og livskvaliteten. I dag bør derfor dei aller fleste pasientane med nydiagnostisert akutt myelogen leukemi vurderast for ei eller anna form for behandling. Artikkelen bygger på eit ikkje-systemisk utval av litteratur samt forfattarane sine eigne erfaringar og vurderingar i samsvar med nasjonale retningslinjer (2).

\section{Klinisk bilete, diagnostikk og klassifisering}

Det kliniske biletet ved akutt leukemi er oftast kjenneteikna ved symptom på raskt progredierande beinmargssvikt, med anemi, blødingstendens ved trombocytopeni og infeksjonstendens ved nøytropeni. Det generelle kriteriet for diagnosen akutt myelogen leukemi er at minst $20 \%$ av alle kjernehaldige celler i beinmargen er myeloblastar (3). Beinmargsaspirat og morfologisk vurdering av May-Grünwald-Giemsa-farga preparat utført av lege med kompetanse i både uttak av aspirat og mikroskopisk vurdering er derfor obligat og bør bli gjort snarleg også hos eldre pasientar. Immunfenotyping av beinmargsaspirat ved væskestraumcytometri i tillegg til genetisk analyse av beinmargen bør derfor gjerast. Det første vil vere viktig for å sikre diagnosen, medan det siste kan ha betyding for val av behandlingsstrategi.

\section{Initial vurdering før behandling}

Vedrørande behandling kan akutt myelogen leukemi delast inn i to hovudgrupper: akutt promyelocyttleukemi og andre former for akutt myelogen leukemi. Akutt promyelocyttleukemi er tidlegare omtala i Tidsskriftet (4) og vil ikkje bli nærmare drøfta her. Denne forma kan behandlast relativt skånsamt og med kurativ intensjon også hos eldre (4). For andre undergrupper av akutt myelogen leukemi er den einaste kurative tilnærminga kurar med intensiv kjemoterapi, eventuelt med påfølgjande allogen stamcelletransplantasjon. Nyare forsking viser at utvalde elles friske eldre pasientar kan profittere på slik intensiv behandling, men ein skal i alle høve vere varsam med slik behandling hos pasientar over 75 år, og det er liten grunn til å tru at pasientar over 80 år har nytte av intensiv behandling (5).

For dei som ikkje er kandidatar for intensiv behandling, finst behandlingsalternativ som 
ikkje blir rekna som kurative, men som kan stabilisere sjukdommen og dermed forlenge livet. Prognose og respons på ulike behandlingar er avhengige av type genetiske endringar i leukemicellene hos kvar enkelt pasient og pasientrelaterte faktorar som alder og komorbiditet. Studiar har vist at prognosen hos eldre pasientar ikkje blir forringa om ein avventar oppstart av behandling inntil initial diagnostikk og vurdering er klar (6).

I Noreg nyttar ein European Leukemia Net (ELN) si risikostratifisering av dei genetiske avvika. Basert på kromosomavvik og mutasjonar i dei leukemiske cellene deler denne risikostratifiseringa pasientane inn i tre prognosegrupper: god, intermediær og dårleg (7). Det er viktig å understreke at ugunstige genetiske avvik førekjem hyppigare hos eldre og at dette sannsynlegvis i seg sjølv er ein prediktor for den dårlege prognosen. Det er også viktig å kartlegge den generelle helsetilstanden og avklare komorbiditet som vil påverke behandlingsvala. Standardiserte skåringssystem for evaluering av funksjonsnivå og komorbiditet er utvikla (1).

\section{Intensiv kjemoterapi og stamcelletransplantasjon}

Når diagnosen akutt myelogen leukemi er stilt, må det bli tatt stilling til om pasienten er tent med intensiv induksjonsbehandling. Initialt er målet å oppnå sjukdomskontroll (remisjon) med morfologisk normalisering av beinmargen og fråvær av cytopeniar utan transfusjonsterapi $(1,7)$. For å oppnå komplett remisjon må ein gi kjemoterapi med så høg doseintensitet at behandlingsrelaterte komplikasjonar kan bli livstruande. Med optimal støtteterapi er terapirelatert mortalitet låg for yngre pasientar $(<5 \%)$, men aukar med stigande alder (8). Diagnostikk og behandling av pasientar som får induksjonsbehandling, skal derfor alltid skje ved hematologisk seksjon på universitetssjukehus eller sentralsjukehus med eigen seksjon for blodsjukdommar, gode blodbankressursar, forsvarleg vaktkompetanse og adekvat intensivkapasitet.

Eldre pasientar har meir komorbiditet, toler behandlinga dårlegare, og sjukdommen responderer ofte dårlegare på behandling enn hos dei yngre (9). Trass i dette har ein i løpet av det siste tiåret blitt merksam på at også eldre pasientar kan tole og ha nytte av meir intensiv behandling (10). For pasientar med god funksjonsstatus og lite komorbiditet, spesielt dersom dei ikkje tilhøyrer ei dårleg prognosegruppe ut frå genetisk risikostratifisering, bør slik behandling vurderast sjølv med alder opp mot 80 år (10) (figur 1). Eit relativt enkelt og mykje brukt system for å vurdere funksjonsstatus er frå Eastern Cooperative Oncology Group (ECOG) (1). For pasientar med ein ECOG-skår > 2 vil ein vere tilbakehalden med å anbefale intensiv behandling. Eldre pasientar utan vesentleg komorbiditet og god funksjonsstatus kan derimot tole slik behandling med relativ låg behandlingsrelatert mortalitet. Studiar frå Sverige har vist at intensivt behandla eldre pasientar kan få auka levetid, og eit mindretal kan oppnå kurasjon (5). 


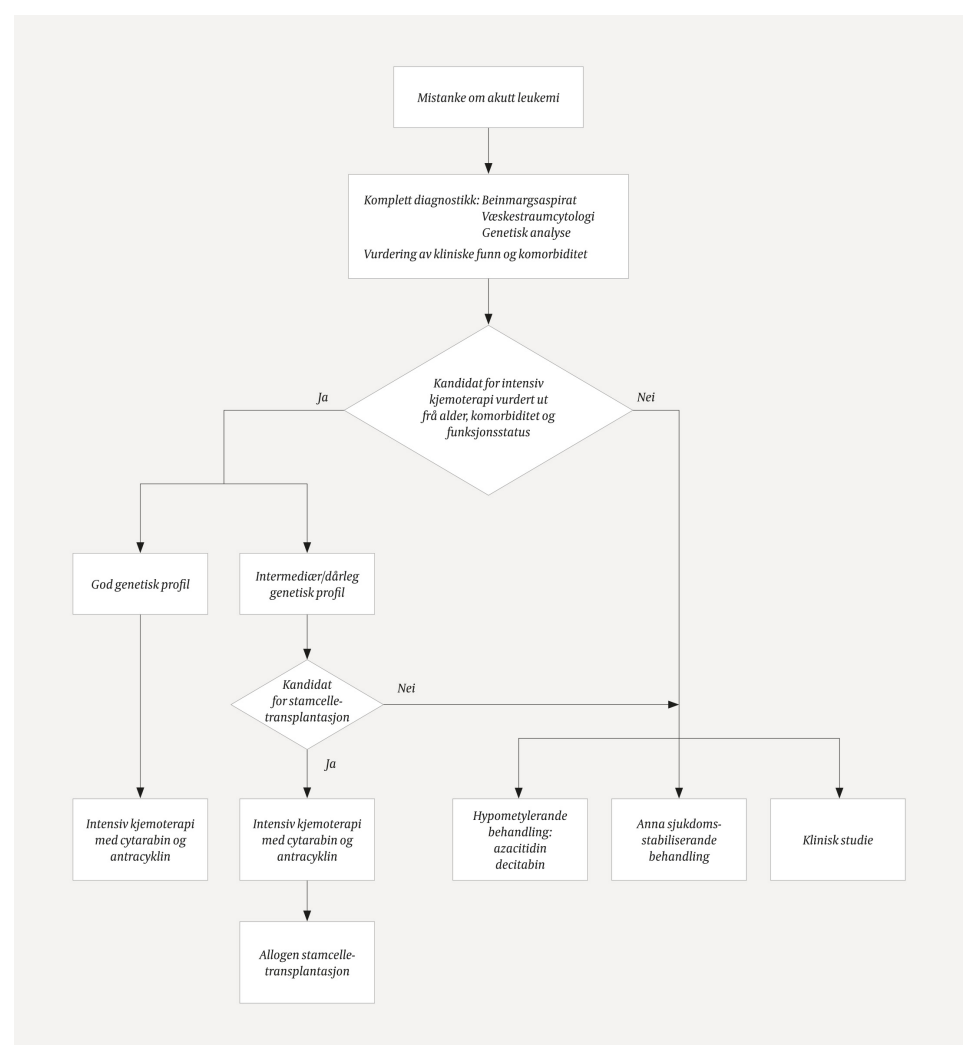

Figur 1 Forslag til utgreiings- og behandlingsalgoritme for pasientar over 65 år med akutt myelogen leukemi.

Sjølv ved oppnådd remisjon vil pasientar med intermediær eller ugunstig prognose ha relativt stor risiko for tilbakefall. Ein bør derfor vurdere allogen stamcelletransplantasjon for pasientar inntil 70-75 år. Nytte av allogen stamcelletransplantasjon må alltid vegast opp mot risiko for terapirelatert mortalitet (11). Dette gjeld særleg eldre pasientar med komorbiditet eller påviste genetiske avvik som predikerer svært dårleg respons på behandling og dermed små sjansar for langtidsoverleving $(7,11)$.

\section{Sjukdomsstabiliserande behandling}

Hos enkelte pasientar står ikkje risikoen ved intensiv terapi i rimeleg forhold til sannsynet for å oppnå meiningsfull effekt av behandlinga. Dette kan vere pasientar over 80 år eller yngre pasientar med andre alvorlege sjukdommar. Ein bør også vere meir tilbakehalden med intensiv behandling hos pasientar der ein av erfaring veit at ein sjeldan oppnår remisjon, for eksempel ved ugunstige genetiske avvik (12). Meir skånsame behandlingsalternativ er ofte det beste alternativet for eldre pasientar som ein ikkje ventar at vil tole intensiv behandling, dvs. har ein uakseptabel høg risiko for behandlingsrelatert mortalitet. Slik behandling gir sjeldan remisjon, men håp om ei tidsavgrensa sjukdomsstabilisering og dermed auka overleving med akseptabel livskvalitet. Behandlinga kan bli gitt ved lokalsjukehus, eventuelt i samråd med universitetssjukehus, og pasientane kan dermed unngå unødig reisetid og hospitalisering. Det er viktig å understreke at ein likevel snakkar om ei relativt kort forventa levetid for majoriteten av desse pasientane.

\section{HYPOMETYLERANDE BEHANDLING}

Hypometylerande behandling verkar ved å hemme enzymet DNA-metyltransferase. Dette gir genhypometylering som medfører reaktivering av gen som vidare leier til programmert celledød (apoptose). To medikament er godkjent i Noreg, azacitidin og decitabin, og desse har i fleire studiar vist å vere eit godt behandlingsalternativ hos eldre pasientar (13). Azacitidin blir rekna som førsteval spesielt ved genetiske avvik som predikerer dårleg prognose (13). Decitabin viste i ein studie å ha ein stabiliserande effekt spesielt hos pasientar med mutasjon i TP53-genet, og denne behandlinga kan derfor vere eit alternativ for slike utvalde pasientar (14). Dersom azacitidin ikkje fungerer som forventa, kan nokre 
unntaksvise pasientar ha nytte av decitabin, men på generell basis bør ein vere varsam med ein slik praksis, då biverknadane ikkje er ubetydelege og sannsynet for behandlingseffekt er svært lågt.

\section{LITE TOKSISK KJEMOTERAPIREGIME}

Lågdose cytarabin gir inntil 20 \% komplett remisjon hos tidlegare ubehandla pasientar, men forventa eittårsoverleving ligg berre på om lag $25 \%$, og åttevekersoverleving er $60 \%(15,16)$. Denne behandlinga har ingen effekt ved genetiske avvik som predikerer dårleg prognose (15). Behandlinga blir ofte tolerert bra og kan bli gitt poliklinisk som subkutane injeksjonar (15). Det er likevel risiko for å bli hospitalisert grunna febril nøytropeni og behov for intravenøs væske, antibiotika og transfusjonar.

\section{ANNA SJUKDOMSSTABILISERANDE BEHANDLING}

Fleire kliniske studiar har vist at behandling med kontinuerleg lågdosert valproat og intermitterande alltransretinsyre (ATRA) med to vekers syklus kvar 4-6 veke, kan auke platetalet og redusere blødningsrisikoen. Denne effekten ser ein først etter om lag tre vekers behandling, og den kan vare frå nokre få veker og inntil eit år. Slik behandling kan kombinerast med andre behandlingsalternativ. Behandlinga kan også ha effekt hos pasientar med sjukdom assosiert med dårleg prognose $(17,18)$, den gir lite biverknader og pasientane kan følgjast poliklinisk. Denne behandlinga bør derfor reknast som eit alternativ i den palliative terapien $(17,18)$.

Ved universitetssjukehusa vil ein ofte ha pågåande kliniske studiar for pasientar med akutt myelogen leukemi som ikkje er kandidatar for intensiv behandling. Dersom ein pasient $\emptyset n s k j e r$ slik eksperimentell behandling, kan ein ta kontakt med aktuelt universitetssjukehus med spørsmål om det har pågåande kliniske studiar som det vil vere meiningsfylt for pasienten å bli inkludert i.

\section{UNDERSTØTTANDE OG PALLIATIV BEHANDLING}

Pasientane får ofte gradvis dårlegare allmenntilstand, og det er ansvaret til den behandlande legen å avslutte leukemiretta og eventuelt også palliativ behandling. Dette må gjerast i samråd med pasient, pårørande og anna involvert helsepersonell (19). Eit mindretal av pasientane vil ut frå ei totalvurdering ikkje vere aktuelle for verken intensiv eller ikkje-intensiv behandling. Pasientane bør kunne vere mest mogeleg heime, handsamast i samarbeid med fastlege og heimebaserte tenester og så langt råd er få behandling poliklinisk med blodprodukt og antibiotika ved behov.

\section{Konklusjon}

Akutt myelogen leukemi hos eldre har tradisjonelt vore assosiert med kort levetid og få alternativ innan leukemiretta behandling. Ein bør i dag ha ei meir aktiv tilnærming til denne pasientgruppa, og eit fleirtal av pasientane kan profittere på ei form for leukemiretta behandling. Framleis vil langtidsprognosen for denne pasientgruppa vere dårleg, men behandling som kan gi forlenga levetid med god livskvalitet, kan og bør truleg bli vurdert også hos dei fleste eldre pasientar med akutt myelogen leukemi.

\footnotetext{
LITTERATUR:

1. Döhner H, Weisdorf DJ, Bloomfield CD. Acute myeloid leukemia. N Engl J Med 2015; 373: 1136-52. [PubMed][CrossRef]

2. Nasjonalt handlingsprogram med retningslinjer for diagnostikk, behandling og oppfølging av maligne blodsykdommer. IS-2746. Oslo: Helsedirektoratet, 2018.

https://helsedirektoratet.no/Documents/Kreft/UTG\%C3\%85TT\%2oIS\%2O2746\%2oNasjonalt\%2ohandlings program\%2ofor\%2omaligne\%2oblodsykdommer\%202018.pdf(23.1.2019).
} 
3. Arber DA, Orazi A, Hasserjian R et al. The 2016 revision to the World Health Organization

classification of myeloid neoplasms and acute leukemia. Blood 2016; 127: 2391-405.

[PubMed][CrossRef]

4. Reikvam H, Hovland R, Bruserud Ø. Akutt promyelocyttleukemi. Tidsskr Nor Legeforen 2014; 134: 1052-5. [PubMed][CrossRef]

5. Swedish AML Group. Most 70- to 79-year-old patients with acute myeloid leukemia do benefit from intensive treatment. Blood 2011; 117:3473-4. [PubMed][CrossRef]

6. Sekeres MA, Elson P, Kalaycio ME et al. Time from diagnosis to treatment initiation predicts survival in younger, but not older, acute myeloid leukemia patients. Blood 2009; 113: 28-36.

[PubMed][CrossRef]

7. Döhner H, Estey E, Grimwade D et al. Diagnosis and management of AML in adults: 2017 ELN recommendations from an international expert panel. Blood 2017; 129: 424-47. [PubMed][CrossRef]

8. Othus M, Kantarjian H, Petersdorf S et al. Declining rates of treatment-related mortality in patients with newly diagnosed AML given 'intense' induction regimens: a report from SWOG and MD Anderson. Leukemia 2014; 28: 289-92. [PubMed][CrossRef]

9. Kantarjian H, Ravandi F, O’Brien S et al. Intensive chemotherapy does not benefit most older patients (age 7o years or older) with acute myeloid leukemia. Blood 2010; 116: 4422-9.

[PubMed][CrossRef]

10. Juliusson G. Older patients with acute myeloid leukemia benefit from intensive chemotherapy: an update from the Swedish Acute Leukemia Registry. Clin Lymphoma Myeloma Leuk 2011; 11 (suppl 1): S54-9. [PubMed][CrossRef]

11. Rashidi A, Ebadi M, Colditz GA et al. Outcomes of allogeneic stem cell transplantation in elderly patients with acute myeloid leukemia: A systematic review and meta-analysis. Biol Blood Marrow Transplant 2016; 22: 651-7. [PubMed][CrossRef]

12. Boddu P, Kantarjian HM, Garcia-Manero G et al. Treated secondary acute myeloid leukemia: a distinct high-risk subset of AML with adverse prognosis. Blood Adv 2017; 1: 1312-23. [PubMed][CrossRef]

13. Dombret H, Seymour JF, Butrym A et al. International phase 3 study of azacitidine vs conventional care regimens in older patients with newly diagnosed AML with >30\% blasts. Blood 2015; 126: 291-9. [PubMed][CrossRef]

14. Welch JS, Petti AA, Miller CA et al. TP53 and Decitabine in acute myeloid leukemia and myelodysplastic syndromes. N Engl J Med 2016; 375: 2023-36. [PubMed][CrossRef]

15. Burnett AK, Milligan D, Prentice AG et al. A comparison of low-dose cytarabine and hydroxyurea with or without all-trans retinoic acid for acute myeloid leukemia and high-risk myelodysplastic syndrome in patients not considered fit for intensive treatment. Cancer 2007; 109: 1114-24. [PubMed][CrossRef]

16. Fenaux P, Mufti GJ, Hellström-Lindberg E et al. Azacitidine prolongs overall survival compared with conventional care regimens in elderly patients with low bone marrow blast count acute myeloid leukemia. J Clin Oncol 2010; 28: 562-9. [PubMed][CrossRef]

17. Fredly H, Ersvær E, Kittang AO et al. The combination of valproic acid, all-trans retinoic acid and low-dose cytarabine as disease-stabilizing treatment in acute myeloid leukemia. Clin Epigenetics 2013; 5: 13. [PubMed][CrossRef]

18. Reikvam H, Hovland R, Forthun RB et al. Disease-stabilizing treatment based on all-trans retinoic acid and valproic acid in acute myeloid leukemia - identification of responders by gene expression profiling of pretreatment leukemic cells. BMC Cancer 2017; 17: 630. [PubMed][CrossRef]

19. Rosland JH, von Hofacker S, Paulsen $\emptyset$. Den døende pasient. Tidsskr Nor Lægeforen 2006; 126: 467-70. [PubMed]

Publisert: 26. april 2019. Tidsskr Nor Legeforen. DOI: 10.4045/tidsskr.18.0775

Mottatt 5.10.2018, første revisjon innsendt 3.1.2019, godkjent 23.1.2019.

(C) Tidsskrift for Den norske legeforening 2020. Lastet ned fra tidsskriftet.no 